\title{
JUDICIAL COMPLEX STRATEGIES IN HUNGARIAN COURTROOM INTERROGATION $^{1}$
}

\section{Marianna VARGA, Ph.D. student}

Hungary 6722 Szeged Egyetem Street 2. University of Szeged, Department of General Linguistics MTA-DE-SZTE Research Group for Theoretical Linguistics vargamariannamanka@gmail.com

\section{ORCID: https://orcid.org/0000-0003-3631-8881}

\begin{abstract}
Taking into consideration the characteristics of the Hungarian culture, language and legal system, this paper aims to study complex interrogation strategies used by Hungarian judges. This research is based on my corpus consisting of 10 Hungarian criminal trials recorded by a voice recorder, and written notes from direct observations. The analysis has a complex nature, since it relies on the results of different scientific disciplines: (1) linguistics - the main goal is to present effective interrogation strategies (2) law - it is crucial to start the research with understanding the function of the discourse type being analysed: the question strategies are

\footnotetext{
$1=\frac{1}{1}-5$ Supported by the UNKP-18-3 New National Excellence Program of the Ministry of Human Capacities. Work on the present paper was also supported by the MTA-DE-SZTE Research Group for Theoretical Linguistics.
} 
intrinsically connected to the institutional role and the legal system by nature, and (3) psychology has also a great role in the investigation of interrogation in two main aspects: the testimony is based on memories and interrogation has an interpersonal part which should not be omitted in discovering the effective question strategies. This research offers rare data related to courtroom interrogation strategies and the results may also have a significant role in legal practice.

Key words: interrogation strategies; courtroom discourses; pragmatics

\title{
KOMPLEKSOWE STRATEGIE SĄDOWE W WĘGIERSKIM PRZESŁUCHANIU SĄDOWYM
}

\begin{abstract}
Abstrakt: Biorąc pod uwagę cechy węgierskiej kultury, języka i systemu prawnego, niniejszy artykuł ma na celu zbadanie złożonych strategii przesłuchań stosowanych przez węgierskich sędziów. Badania oparte są na korpusie składającym się $\mathrm{z} \quad 10$ węgierskich procesów karnych zarejestrowanych przez dyktafon oraz pisemnych notatek $\mathrm{z}$ bezpośrednich obserwacji. Analiza ma złożony charakter, ponieważ opiera się na wynikach różnych dyscyplin naukowych: (1) językoznawstwa - głównym celem jest przedstawienie skutecznych strategii przesłuchań (2) prawa - ważne jest, aby rozpocząc badania od zrozumienia funkcji analizowanego typu dyskursu, ponieważ strategie pytań są $\mathrm{z}$ natury nierozerwalnie związane $\mathrm{z}$ rolą instytucjonalną i systemem prawnym, (3) psychologii, która odgrywa również wielką rolę w badaniu przesłuchań $\mathrm{w}$ dwóch głównych aspektach, ponieważ zeznania oparte są na wspomnieniach i przesłuchaniach, które cechują się interpersonalnością, której nie należy pomijać w odkrywaniu skutecznych strategii pytan. Badanie to oferuje rzadkie dane związane ze strategiami przesłuchań w sądzie, a wyniki mogą również odgrywać znaczącą rolę w praktyce prawnej.
\end{abstract}

Słowa klucze: strategie przesłuchań; dyskursy na sali sądowej; pragmatyka

\section{Introduction}

The present paper aims to show the functions and types of questions used by Hungarian judges in criminal courtroom proceedings. This work also presents linguistic tools and strategies applied when asking these questions. The presented research therefore has a complex nature. It pertains to linguistics, because it aims to discover effective 
linguistic strategies of courtroom communication, but at the same time the topic is closely related to law and psychology, too. The interrogation strategies depend on the given legal system, therefore the strategies should be explored in that context. In the literature there is a considerable interest in interrogation strategies, but most of this research analysed the Anglo-Saxon cross-examination method, and focuses on the opposite parties' strategies, how lawyers control and handle the testimonies (Stone 1995, Eichelbaum 1989, Walton 2008b, Archer 2011, Henderson, Hefel and Kebbel 2016, Catoto 2017). In the continental legal system, such as Hungarian, the judges' institutional role is to interrogate the witnesses in a thorough and unbiased way. Therefore, the functions of these questions absolutely differ from the Anglo-Saxon method. Apart from this, interrogation is an interpersonal activity, and the questions are mostly oriented to memories of the interrogated persons, therefore psychology also has an essential role in mapping the interrogation strategies. In what follows Section 2 presents the current state of affairs in relation to continental courtroom interrogation. Section 3 explains the Hungarian legal system and the functions of judges' questions, because it is crucial to start the research with understanding the function of the discourse type being analysed. Section 4 discusses the theoretical background, Section 5 introduces the analysed legal corpus, Section 6 shows the interrogation strategies and Section 7 summarizes the results.

\section{State of the art}

Although the spotlight is on the cross-examination method, there are researchers which study direct questioning. Opaibi (2008) investigates Nigerian civil law interrogations and he determines three types of questions which based on Schiffrin's (1994) categorization, such as:

(1) information-seeking questions: In regard to Searle's felicity conditions in the relation of questions in which the speaker lacks knowledge of a particular state of affairs (preparatory rule) and they try to gain that knowledge (sincerity rule) in the way of eliciting information from the person being interrogated (essential rule). (e.g. Do you know the defendant? or Was there any letter to that effect?) 
(2) information-checking/confirmation-seeking questions: These questions fulfil the sincerity, preparatory and essential conditions of information-seeking questions, and they can appear in several forms: interrogative sentences, tag questions, rising intonation on a declarative statement or part of a statement (e.g. Answer: He wrote an agreement between his mother and himself and they were about to enter the agreement but it was not signed because she passed away. Question: She did not sign?)

(3) action-elicitation questions: These provide information leading to immediate actions in the context of the discourse (e.g. Any objections?)

Haijuan (2019) investigates Chinese criminal trials and she also determines three types of questions:

(1) keyword questions: These questions focus on the most significant information with elliptical forms. Most of these questions appear at the beginning of the interrogation, such as identity verification. These questions are short and have a relatively fixed verbal routine (e.g. What is the name of the defendant?)

(2) confirmation questions: The questioner's aim is to warrant that the interrogated person fully understands what is said and what is implied in order to avoid misunderstanding and to enhance the mutual knowledge (e.g. Defendant Chen Junfu, are you clear with the testimony presented by the Prosecutor?)

(3) consultative questions: These questions are seeking possible responses from the person being interrogated in a way in which the questioner could avoid being subjective and biased (e.g. Defender, do you have any other opinions? or Defender, do you have any question?).

Bednarek (2014) investigates the types of questions in reconstruction of objective reality in Polish criminal trials. She emphasizes the question which enables the interrogated person to give an unrestricted free answer about the case, involving all the necessary information about the crime (e.g. What do you know in connection with the committed crime?) After this free speech, detailed questions take place in order to elucidate ambiguities and inconsistencies (e.g. You testified at the police station that the theft of your son's mobile telephone was to your detriment. Why did you say so?) These questions formally are yes-no questions and wh-questions, both types are used almost on equal terms during the interrogation. With regards to the data, Bednarek argues there are no special techniques in which 
certain types of questions appear to be preferable over others during the examination of the defendant and witnesses (2014: 147).

These above mentioned works focus not only to questioning the witnesses, defendants and experts, but also include questions for the prosecutor and the attorney. In this article I will investigate the functions of judges' questions specifically intended for the interrogated person and I will start the analysis with the consideration of the goals of the judges' questioning to be able to get a more detailed analysis.

\section{Hungarian legal system and the functions of judges' questions}

Firstly, the most important characteristics of Hungarian legal system are necessary to determine the functions of judges' questions. In the Hungarian legal system, the judges' role is to interrogate the defendants and interview the witnesses in an unbiased way, therefore the Hungarian question strategies significantly differ from the adversarial war-like cross-examinational method. Before the court procedure, in the discovery and pre-trial stage the main question is to find out What happened? Contrary to this, in the criminal trial the judge already knows the facts of the case from the indictment and other attached documents, therefore, in the court procedures the judge focuses on the question Whether the details of the indictment really happened or not? (Farkas and Róth 2004, Bócz and Finszter 2008, Orosz 2016). Within the courtroom procedure the question strategies are intrinsically determined by the professionals' role. While the prosecutor and the defence attorney try to influence the witnesses to confirm their statements, the judges consciously attempt to minimize the influencing characteristics of their own questions in order to give an equitable judgement and also to preserve the honour and credibility of the court. The other main attempt is to induce the interrogated person's cooperativity when it is necessary. In regards to this information, 3 main types of questions can be determined by their functions in the interrogation. These are: 


\section{Non-substantive part (or initiative part) of the interrogation}

(1) Rule-governed questions: these questions are mostly present in the first part of the interrogation (Farkas and Róth 2004, Bócz and Finszter 2008, Orosz 2016, Vinnai 2018). These questions could be asked even if the defendant or the witness denies answering the questions of the substantive part of the interrogation, where the testimony and the confession took place. These questions include identification, personal circumstances such as marital status, public debt, financial circumstances, the relationship between the defendant and the witness, etc. The judges have to warn the defendants and witnesses about their rights and duties, and the judge has to ascertain that the person understood what they just said. These questions are crucial, because if the judge leaves it out, the testimony cannot be used as evidence. This question type is similar to key-word questions, but it involves all the necessary questions which should be asked in this initiative part and it is important from the aspect of criminal proceeding (cf. Haijuan 2019). These questions also have an essential role from a psychological aspect. Since these questions have no connection whatsoever to the matter under investigation, these do not present a real threat to the interrogated person, but they are at a heightened emotional state already, therefore they give the opportunity to the judge to observe the interrogated person's normal behaviour in this heightened emotional situation (Bócz and Finszter 2008, Gordon and Fleisher 2011, Orosz 2016).

\section{Substantive part of the interrogation}

(2) Information-seeking questions: the judge's focus is to complete the gaps in the story of the case and specify the details. These questions comply with Schiffrin's (1994) and Opaibi's (2008) description, namely when the speaker lacks knowledge of a particular state of affairs and they try to gain that knowledge by asking it from the hearer. This type of question is not comparable with Haijuan's (2019) consultative question, because the former is not necessarily unbiased, whereas consultative questions are unbiased.

(3) Controlling questions: these questions do not simply check the information (cf. Opaibi's confirmation seeking question 2008) and not only check the understanding (cf. Haijuan's confirmation questions 2019). This type of question's aim is (a) to check the information 
written in the indictment, (b) to try to find out if the interrogated person says facts or only their own opinions about the facts, (c) to ascertain there is no misunderstanding (d) to try to ascertain their credibility, in other words, if they are saying the truth or if they are distorting the truth (e) to find out whether the witness recalls a true experience or only a false memory.

These are the main functions of the questions asked by judges, in order to make their decision. In the next Section, I will present the linguistic framework of the research.

\section{Theoretical background}

Verschueren's (1999) approach using language is nothing else than continuously making linguistic choices in a conscious or unconscious manner. These choices are made at any level of linguistic form and choices are also made concerning linguistic strategies. Strategies of language use are ways of exploiting the interplay between explicitness and implicitness in the generation of meaning. ${ }^{2}$ The choices between alternatives of linguistic forms and strategies have message value, independently from the speaker's intention. For this reason, using linguistic strategies does not mean intentionally manipulating or disorienting the hearer, because the speakers have a wide range of possibilities to express themselves, therefore they need to choose between the alternatives. Every utterance directs the hearer's attention and comprehension to some degree, so every utterance has some kind of effect on the hearer (Nemesi 2011, Tátrai 2011). In this sense I use the term verbal influence as a broad category, in which it is not necessarily an intentional and conscious action, rather a necessary characteristic of verbal communication, because every utterance has an effect on the hearer to a certain extent. I use the term as follows (cf. Árvay 2003, Nemesi 2011):

\footnotetext{
${ }^{2}$ I use the term implicitness broader than its general use in the pragmatic literature. I refer not only to implicatures, but also information from sentence construction, information from the usage of functional elements and inflections.
} 


\section{Marianna Varga: Judicial Complex Strategies...}

When influenced by verbal language use, the communicator's expression in the hearers develops a particular opinion and strengthens or alters their existing knowledge, opinions, and attitudes.

The next issue is how a question influences the answer. The influential nature of questions depends on how they shape the answer and which conclusions a hearer draws (Semin and De Poot 1997). Consequently, in the examination of questions it is essential to investigate question-answer pairs and we have to consider the classical semantic question types besides the pragmatic functions, because as it is well known, the semantic categorisation differentiates the questions by the answers provided to it (Kiefer 1983, Groenendijk and Stockhof 1989, Maleczki 2007, Gyuris 2016):

(1) Yes-no questions (p, p)

a) A testvérével volt a helyszínen?

'Were you with your sibling on the spot?'

b) A testvérével volt-e a helyszínen?

'Were-E you with your sibling on the spot?'

c) Nem a testvérével volt a helyszínen?

'Weren't you with your sibling on the spot?'

\section{(2) Alternative questions ( $p, q)$}

A testvérével, vagy a barátnőjével volt a helyszínen?

'Were you with your sibling or your girlfriend on the spot?'

(3) Wh-questions $\left(x_{1}, x_{2} \ldots x_{n}\right)_{G i}^{3}$

Kikkel volt a helyszínen?

'Who were you with on the spot?'

\section{(4) Open questions $\left(\mathbf{P}_{1}, \mathbf{P}_{2} \ldots \mathbf{P}_{m}\right)$}

Miért mondta, hogy hárman voltak, ha nem volt ott a testvére?

'Why did you say, three of you were there, if your sibling was not there?'

The set of answers of a yes-no question has two elements, both of them a proposition, where either of them is the negation of the other

\footnotetext{
${ }^{3}$ Where Gi is the grammatical category - which is determined by the interrogative or the noun after the interrogative.
} 
one. In Hungarian, these questions can be formulated negatively (1c) and positively in two different ways (1a-b) (Kenesei, Vago and Fenyvesi 1998, Gyuris 2016). In example (1) b an -e question particle is attached to the verb. The usage of $-e$ question particle in yes-no questions is highly characteristic of the judges' speech style in Hungarian courtroom discourses (Varga 2015: 101). The possible explanation for this phenomenon is that $-e$ particle is able to ease the positive interpretation of the question and eliminate the speaker's own preference or bias (Schirm 2011), therefore this particle is also referred to as anti-bias particle (Gyuris 2016). Alternative questions differ from yes-no questions, because the two propositions do not exclude one another, in other words $\mathrm{p}$ and $\mathrm{q}$ could be both true at the same time. In some cases the yes-no questions can be formulated as a structure of alternative question. The set of answers of wh-questions is potentially infinite, but in the concrete speech situation the number of the possibly given answers is determined pragmatically. The interrogative or the noun after the interrogative restricts the answers. The set of answers of the open questions are also potentially infinite, although it is generally determined pragmatically. The crucial difference is that the set of answers of open questions is not determined pragmatically at all (Kiefer 1983).

Beside the question's form Olge et al. (1980: 43) and Walton (2008b: 322) determine some other factors which are able to suggest a desired answer. These are: emphasis on certain words, the questioner's tone, the questioner's nonverbal conduct, the questioner's inclusion of facts still in controversy. I will refer to these question types and aspects in the analysis and the determination of interrogation strategies. But before the analysis, I will introduce the legal corpus in the next Section.

\section{Legal corpus}

The analysed corpus involves recordings and written notes about nonverbal communication of 6 Hungarian criminal trials from 2017. Due the Secrecy Obligation, I publish the summarized data: the corpus includes money laundering, manslaughter and criminal attempt to homicide. I recorded these trials with a voice recorder and 
I anonymized and transcribed the texts using the method of Conversation Analysis (Jefferson 1984). ${ }^{4}$ This research is based on:

(1) Interrogations of eight defendants: The defendants are not obliged to make deposition during the courtroom trial. In case a defendant refuses deposition, the judge reads out that deposition which they already made in the discovery and pre-trial stage. In general, defendants uphold their earlier deposition, and refuse to do it again at the trial. From these eight persons six refused it, but all of them cooperatively answered the questions about their personal circumstances (e.g. marital status, public due, financial circumstances, etc.). The refusal has no consequences on their right to questioning and making observations. The other two defendants have answered the substantial questions, too.

(2) Testimonies of nine witnesses: A witness may be able to refuse a deposition but only in certain circumstances. From these witnesses all of them had to answer the questions.

(3) Two presiding judges in criminal proceedings control how hearings and trials unfold in the courtrooms.

In what follows, I turn to the analysis and demonstrate the question strategies in connection with the functions of the questions.

\section{Analysis}

In the substantive part of the interrogation information-seeking and controlling questions are dominant. In the first example the judge checks a piece of information written in the indictment. The judge tries to find out if the interrogated person states facts or opinions. In this example the judge knows from her earlier testimony that the witness could not visit one of her relatives. The judge checks it at the trial, and when the witness expresses epistemic modality with the verb feel, the judge asks evidence for this statement.

\footnotetext{
${ }^{4}$ The relevant transcription nominations are detailed in the Appendix.
} 
(1) Judge: Állítása szerint a személyes látogatásnak valami akadálya van?

'You claim there is an obstacle to a personal visit?'

Witness: Úgy érzem meg se tudnám közelíteni.

'I feel I cannot even approach him. '

Judge: Próbálta már és akkor elküldték?

'Have you already tried and were sent away?'

Witness: Nem.

'No.'

Judge: Akkor ez csak feltételezés?

'So this is only an assumption?'

Witness: Yes.

'Igen.'

In this excerpt all of the four questions are positive yes-no questions which include the judge's presuppositions, because questions always contain the speaker's presuppositions in some way, although it could be harmless (Levinson 1983, Walton 2008a, 2008b, Hayano 2013). Presuppositions are pieces of information which the questioner considers as a given. Presuppositions appear implicitly in the utterances, their recognition happens by linguistic conventions (Tátrai 2011). Consequently, a question could be influential by its presupposition, especially if the presupposition is false. The reason is that the person being interrogated has two goals at this time: (1) s/he responses directly to the question and so s/he accepts the presupposition, or (2) s/he makes the presupposition explicit with plus interactional power and denies it, but this could characterise a person who does not want to answer specifically to the question (Walton 2008; Hayano 2012).

A presupposition in a yes-no question is that the speaker thinks one of the answer out of the two possibly given answers as true (Walton 2008). It means in excerpt (1) that the judge thinks it is true that there is an obstacle to personal visit, the witness already tried and was sent away, but at least it will be clear that these are only assumptions. Contrary to this, it is really important to see here that the judge does not want to influence the witness intentionally, the judge's goal is to control a statement she just read in the witness' earlier testimony and she asks evidence for it. The judge tries to discover the 
evidence in order to dive in the given case, but if this question would have been asked from a prosecutor as an example, it could be really influential in the judge's eyes, because this type of question bears the possibility of influencing. If we turn to the example (2), we can see judges usually attempt to avoid presuppositions, and keep the order of questions. He starts to ask how much alcohol the witness drank, but he suddenly corrects it, and at first he asks whether he drinks alcohol, or not at all. It is really important that the judge knows from the defendant's earlier interrogation, since the defendant said it himself he had drank a lot and had committed the crime as a consequence of that.

(2) Judge: Addig mennyi, fogyasztott-e szeszes italt?

'How much, did you drink-E any alcohol?'

Defendant: Fogyasztottam.

'Yes, I did.'

Judge: Emlékszik-e arra, mennyi szeszes italt fogyasztott?'

'Could you remember how much alcohol did you drink?'

Defendant: Hát addig körülbelül egy üveg bort,

'Well, till that time about a glass of wine,'

Judge: Egyedül?

'Alone?'

Defendant: Nem, a barátommal.

'No, with my friend.'

Judge: Arra vagyok kíváncsi, Ön mennyit fogyasztott.

'I am curious about how much alcohol you drank.'

What we see here is that the judge eliminates the presupposition (that the witness drank any alcohol) and then asks a yes-no question with an - $e$ question particle, which eliminates his preference (that the defendant did drink alcohol). When the defendant says he did drink alcohol, it becomes a mutual knowledge in the context, and then the judge asks about the amount of alcohol. Then the defendant starts to give details about it, but the judge interrupts it, and asks if the defendant drank the amount by himself. It is interesting because it is a positively formed as a yes-no question, but the judge knows from the documents that the defendant was with their friends. Therefore he wants to clear up the information, and so the defendant can claim he was not alone. It could be a possible reason for the positive yes-no question, that in the context there is the evidence, that the defendant lists the alcohols he drank alone, because that was the question. So 
here the contextual bias appeared, not the epistemic bias, that the judge's prior knowledge is that he drank this bottle of wine with his friends. ${ }^{5}$ Example (3) shows the importance of eliminating prior knowledge. The judge knows the witness' earlier testimony, but she does not automatically enrich the manager noun phrase with the given information, she is interested in this information before she asks the content of the letter. In this case the judge realises a contradiction which she has to resolve. This is really common in courtroom interrogations, judges try to circumstantially interrogate the witnesses without previous knowledge and any presuppositions they might have, so they generally try to express the least of what they already know.

(3) Judge: Ki volt akkor a cég vezetője akinek kiküldésre került ez a levél?

'Who was the manager to whom the letter was sent?'

Witness: $\quad$ Nagy Zoltán ügyvezetőnek küldtünk levelet illetőleg utána a bíróság is Nagy Zoltán ügyvezetőt hívta fel arra hogy ezeknek a kötelességeknek tegyen eleget.

'We sent the letter to manager Zoltán Nagy and then the court also called on Zoltán Nagy, to fulfill these duties.'

Judge: Nagy Zoltán? Nem Kiss Aladár?

'Zoltán Nagy? Not Aladár Kiss?'

Witness: Parancsol?

'Excuse me?'

Judge: Nem a Kiss Aladár?

'Not the Aladár Kiss?'

Witness: Nem. A Nagy Zoltán.

'No. Zoltán Nagy.'

Judge: Korábbi vallomásában azt mondta, hogy a Kiss Aladár. Azért kérdezek rá.

'In your earlier testimony you said, that it was Aladár Kiss. That's why I asked.'

In the next excerpt the judge attempts to ascertain there is no misunderstanding. The prosecutor asks the witness:

(4) Prosecutor: Ezt ki csi (0.5) ezt ki tette volna meg? Ugyanaz aki az autót is?

\footnotetext{
${ }^{5}$ For the types of bias see e. g. Ladd (1981) Sudo (2013), Gyuris (2016).
} 
'Who would (0.5) Who would have done this? Was it the same person who did it with the car, too?'

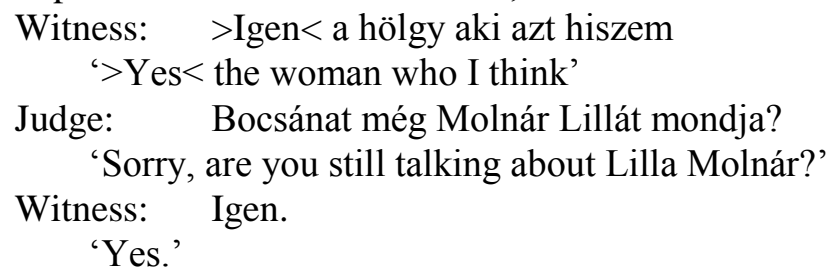

Before the prosecutor's question, the judge interrogated the witness who was talking about Lilla Molnár. Despite this, the judge does not automatically accept this inference, she checks if they are really referring to the same person. Here the judge uses positive yes-no question because of the contextual bias caused by talking about Lilla Molnár prior to the trial.

In example (5) the judge tries to ascertain the witness' credibility. In several cases these questions try to explore if the witness could clearly observe the actions, or the witness may be biased. In this example the judge is interviewing a woman who was sitting in a pub with her new boyfriend, when her ex-boyfriend arrived to the same place and the two men got into a fight and one of them stabbed the other with a knife. The judge asks about the amount of alcohol she drank to try and find out the state she was in. The first question does not involve presupposition, because the witness told him earlier they went to the pub to drink and talk. Contrary to this, the second question involves presupposition (two pints of beer). Bócz and Finszter (2008) argues it is influential to ask in this way the amount of alcohol, the first question should be an alternative question: Did you drink draught beer or beer from a bottle?

(5) Judge: Mennyi alkoholt fogyasztott ön a presszóban?

'How much alcohol did you drink in the pub?'

Witness: Két sört ittam.

'I drank two beers.'

Judge: Két korsó sört?

'Two pints of beer?'

Witness: Nem, két kis pohárral.

'No, two little glasses of beer.' 
Judges also use strategies to find out whether the witness recalls a true experience or only a false memory. They try to clear up the source of the witness memory, and find out if they really saw or heard the part of the crime or they just heard about it from someone else. Therefore they use source-monitoring questions (Reyna et al. 2016) such as:

(6) a) Na most ezt ott a helyszínen mondta ö önnek? (1.0) vagy utólag?

'So, he told you on the spot? (1.0) Or later?'

b) Később beszélt ön a Péterrel?

'Did you speak with Péter later?'

c) A nagynénje. Amikor ön odaért. Akkor elmondta-e. Ő maga. Hogy mi történt.

'Your aunt. When you arrived. Then she said it to you. She herself. About what happened?'

As we could see, information checking questions have a really important role in courtroom interrogation, but information-seeking questions which aim to complete the gaps in the story of the case and specify the details are also important. There is another possibility to eliminate the speaker's bias in the question. Instead of a yes-no question the judge gives alternatives and uses an alternative question form. Giving alternatives could be an influential strategy, if the questioner gives alternatives which are false, do not exist, or are simply impossible (Walton 2008b). Therefore, it is really important that the judge gives alternatives only if the possible alternatives can be determined exactly such as example (7)-(8), where the judge seeks information. In excerpt (7) the judge combines alternatives with $-e$ question particle in order to eliminate his bias.

(7) Judge: melyik (0.5) ö mozgás indult el hamarabb, illetőleg a kettő között mérhetö-e valamifajta idő, hogy elöbb indult el a sértett neki balra és utána indult el az autó ugyanabba az irányba. az autó a menetirány szerinti jobb oldalba, vagy egy időbe, vagy egyik, hát különbség, ki volt előbb, mennyivel volt elöbb, ezt meg lehet-e állapítani?

'which (0.5) movement started earlier, i.e. is there any time measured between the two, who started pacing towards the other, and then the car went in the same direction. Can it be determined who initiated it?' 
Expert: álláspontom szerint meg lehet állapítani ( )

'my standpoint can be determined ( )'

(8) Judge: A verekedés előtt vagy után vette a kést?

'Did he buy the knife before or after the fight?'

In the following example (9) the judge does not know the correct medical term for the phenomenon, therefore he indicates with rising intonation he is waiting for the expert answer to pronounce the correct term. He does not give alternatives in order to avoid the influential effect.

(9) Judge: Egy kérdésem van még. Azok a tünetek, amiket a vádlott maga mond el, ezek milyen tünet, milyen (1.0) súlyosságú tüneteknek számítanak ezek >ezek< enyhe tünetek, ezek, (2.0)

'I only have one more question. The symptoms that the defendant says, what kind of, sym, how severe symptoms are these, these are, slight symptoms, these, (2.0)'

Expert: Ö én ezt nem is így értékelném, hogy enyhe, hanem hanem részleges tün[eteknek]=

'Hm. I would rather say these are partial symptoms than severe'

Judge: [részleges]

'[partial] ‘

As we could see in example (9) the word selection should be carefully made in the questions. In criminal trials it is so important to discover the defendant's intentions. In excerpt (10) the judge asks first the change in the state of the pilot wheel with the verb start (elindul). He does not speak in the first line about who started to make these changes. This division gives the opportunity to speak separately about the event and the will and intention of the defendant.

(10) Judge: tehát ha jól értem, a sértett balra történő mozgását megelőzően 0.3 másodperccel indul el az autó kormány(.)nyában a a tehát a kormányzásának a változása

'so if I am correct, before the victim started to go to their left, the steering wheel of the auto, i.e. the direction changed'

Expert: igen 
'yes'

Judge: ezt megelőzően van nyilván a vezetőnek a vádlottnak a szándék kialakulása

'the driver's, the defendant's statement developed prior to this'

In word selection it is also important to choose precisely between the words which are connected to the same semantic schema. Gordon and Fleisher (2011: 90-91) argues questions must not include emotionally charged words (rape, steal, kill) where the language itself might cause psychophysiological responses. It is also not favoured to use intimidating legal words because those could be ambiguous and also allow the guilty interviewee to hide behind a rationalization (I did not take a bribe; I accepted pay for a special job). Beside these I found that judges try to not confuse the words used for the same event, they always choose the way to speak about an event in the manner the interviewed person used earlier. For example, in a case the event where an animal and an old woman had an accident the witnesses described in the following ways: crash, bump into, run into, hit, stumble, tumble, ram, knock over, push, push over, sweep away, etc. See also excerpt (11)-(12).

(11) Judge: A vallomásában azt mondta ön, hogy „a Péter azt mondta hogy csak megijedtek a 0.5 megijedt az állattól nagynéném de nagynéném mérgesen mondta is hogy nem igaz. Mert kerékpárostól fellökte ( )" Tehát ő vitatkozott ezzel, hogy csak megijedt volna már ott a helyszínen is? Az ön nagynénje vitatkozott ezzel? Hogy fel is lökte őt ez az állat?

'In your statement you said „Péter said they were just scared from $0.5 \mathrm{my}$ aunt was afraid of the animal but my aunt said angrily it was not true. Because he bumped into her on her bike ( )" So she does not agree that she was only scared of the sport? Your aunt disagreed with this? That he bumped into her?'

Witness: (1.0) igen

'(1.0) yes'

(12) Judge: Mit tapasztalt a helyszínen? Önben összeállt-e a kép akkor ott a helyszínen hogy mi történhetett? 


\section{Marianna Varga: Judicial Complex Strategies...}

'What did you experience on the spot? Did you have a clear picture there on the spot what could have happened?'

Witness: Nem, utólag derültek ki dolgok hogy mi is történt. A Tanú2 ott volt akkor tehát ö úgy mondta hogy Beáta néni elesett, később derültek ki a dolgok ( ) mondta hogy elesett biciklivel. Később derült ki hogy (.) nekirontott egy állat és lelökte őt a kerékpárról.

'No, it was clear only later what happened. Witness2 was there then and they said that aunt Beáta fell, it turned out later that she fell from her bike. And it turned out even later that an animal bumped into her and she fell of her bike.'

This strategy is really important in order to gain accurate answers from the participants. If the judge confused the words, it could cause false memory retrieval (Loftus \& Miller \& Burns 1978, Lindsay and Johnson 1989, Loftus 2003, Brainerd \& Reyna 2005, Laney \& Loftus 2016) and the interrogated person may confirm a description which actually was not the most correct description about the event. Those strategies which heighten the cooperativity are also essential in information seeking. In example (13) the witness is 20 years old and a bit shy and does not really want to answer the questions.

Judge: Ki volt még a háznál ekkor? Tomi, maga, Balla, Robi. Idáig biztosak vagyunk, ugye?

'Who else was at the house at this time? Tomi, you, Balla, Robi. This much we are sure about, aren't we?'

Witness: Bence és Bálint.

'Bence and Bálint.'

The judge uses the expression "this much we are sure about, aren't we?" meaning himself and the witness with the we inclusive person deixis which expresses a sense of unity and belonging to the hearer. She expresses mutually collected information in an understanding way and uses emotional identification with the attitude of the witness. With this strategy the judge expresses her cooperation and mitigates the threat of the obligation to answering. The question is a positively formed tag question, and asks for confirmation, but it does not involve any new information, only names listed by the witness.

Now I turn to the rule-governed questions which are usually simple wh-questions or yes-no questions. In example (14) we can see 
the judge keeps the order of the questions. She asks in the first line with a yes-no question and $-e$ question particle if the defendant has any debt, and only in the second line does she try to discover the amount of the debt.

(14) Judge: Van-e köztartozása?

'Do you have-E any debt?'

Defendant: Igen.

'Yes, I have.'

Judge: Mennyi köztartozása van?

'What is the amount of your debt?'

Defendant: Körülbelül 3 millió forint.

About 3 million forints.

In example (15) the judge asks if the defendant understands the warnings or not. In this example it is a positive yes-no question, but it also rarely occurs with $-e$ question particle. A possible reason could be that the confession could not be evidence if this question is not confirmed. If the defendant says they do not understand the warnings, the judge must explain it and reformulate it.

Judge: Megértette a figyelmeztetéseket?

'Do you understand the warnings?'

In my last example I would like to show a difference between rulegoverned questions vs. information-seeking and controlling questions. The judge also keeps a strict order of questions and uses the $-e$ particle in yes-no questions, because it characterises the judges' speech style. But here they express their preference and inferences (e.g. So do you have a kid?) more times. A possible reason could be that this initiative part of the interrogation does not contribute to the substantive part of the interrogation in where the judges try to gain the evidence, these questions do not have any connection to the committed crime.

(16) Judge: Van-e valami más jövedelme?

'Do you have any other form of income?'

Defendant: Nekem nincs, az élettársamnak van.

'I do not, but my partner does.'

Judge: Jó, azt mindjárt megbeszéljük akkor. Ön nem nős, ugye? 
'Ok, we will discuss this then. You are not married, right? Defendant: Hát nem vettem el feleségül, de rendesen a feleségemmel van egy egyéves kislányunk.

'I did not marry her, but we have a one-year old daughter.' Judge: Tehát nőtlen, de élettársi kapcsolatban él.

'So you are married, but you live in a domestic partnership.' Defendant: Igen.

'Yes.'

Judge: Hogy hívják az élettársát?

'What is your partner's name?'

Defendant: Nagy Virág.

Judge: Mivel foglalkozik?

'What does she do?'

Defendant: Főállású anya.

'She is a full-time mother.'

Judge: Mennyi a segély, amit ezért kap?

'How much is the benefit she gets for this?'

Defendant: Negyvenezer forint.

'Forty thousand forints.'

Judge: Kiskorú gyermeke akkor van önnek?

'So do you have a minor child?'

Defendant: Igen.

'Yes.'

\section{Conclusion}

Three types of questions can be determined by the function of the judges' questionings. These questions are: rule-governed questions, information-seeking questions and controlling questions. During the interrogation, judges in the Hungarian legal system have two general goals, (1) they try to heighten the cooperativity of the witnesses when it is necessary and (2) they try to minimize the influential properties of the questions, in other words, they try to give only a question frame with the minimal information for the sake of an uninfluenced answer. This attempt is mirrored in word selection, elimination of presuppositions, keeping the order of the questions, avoiding directed questions by providing alternatives when the possibilities can be 
exactly determined and using the $-e$ question particle as an anti-bias particle. The judges make an attempt to avoid the influential properties of questions is crucial in information-seeking questions. Presuppositions and speaker's preference occur mostly in rulegoverned questions and in controlling questions in order to ask for confirmation. This article aims to present the complex nature of the judicial questioning strategies in the criminal courtroom proceedings. These strategies do not form a taxative, closed group by nature, but the results may have a significant impact in legal practice and law education.

\section{Bibliography}

Archer, Dawn. 2011. Cross-examining lawyers, facework and the adversarial courtroom. Journal of Pragmatics 43: 3216-3230.

Árvay, Anett. 2003. A manipuláció és a meggyőzés pragmatikája a magyar reklámszövegekben [The pragmatics of manipulation and conviction in Hungarian commercials]. In Németh T. Enikő - Bibok Károly (Eds.) Általános Nyelvészeti Tanulmányok XX. Tanulmányok a pragmatika köréböl. Budapest: Akadémiai Kiadó. 11-35.

Bednarek, Grazyna Anna (2014) Polish vs. American Courtroom Discourse. Inquisitorial and Adversarial Procedures of Witness Examination in Criminal Trials. New York, Palgrave Macmillan.

Bolinger, Dwight L. 1957. Interrogative Structures of American English: The Direct Question. Alabama: University of Alabama Press

Bócz Endre (2008) Kriminalisztika a tárgyalóteremben [Criminalistics in the courtroom]. Budapest, Magyar Közlöny Lap- és Könyvkiadó.

Bócz, Endre and Finszter Géza. 2008. Kriminalisztika joghallgatóknak [Criminalistics for law students]. Budapest: Magyar Közlöny Lap- és Könyvkiadó.

Catoto, Jerson. 2017. On courtroom Questioning: A Forensic Linguistic Analysis. Journal of Humanities and Social Science 22(11): 65-97. 
Edenborough, Robert. 2002. Effective Interviewing: A Handbook of Skills and Techniques (2nd edition). London: Kogan Page.

Farkas Ákos and Róth Erika. 2004. A büntetöeljárás [Criminal procedure]. Budapest: CompLex Kiadó.

Gálig, Péter. 2011. A kihallgatás etikája és taktikája [The ethics and tactics of interrogation].

[http://www.jogiforum.hu/publikaciok/451]

Groenendijk, Jeroen and Martin Stokhof. 1989. Type-shifting rules and the semantics of interrogatives, in Properties, types and meanings.

Gyuris, Beáta. 2016. A magyar eldöntendö kérdö mondatok tipológiájához [To the typology of Hungarian yes-no questions. Jelentés és Nyelvhasználat 3: 169-190.

Haijuan, Hu. 2019. Courtroom questioning Adapted to Legal Procedures. English Language Teaching 12(1): 7-17.

Hayano, Kaoru. 2012. Question design in conversation. In Jack Sidnell - Tanya Stivers (szerk.) The Handbook of Conversation Analysis. Oxford: Wiley-Blackwell. 395-414.

Jefferson, Gail. 1984. On the organization of laughter in talk about troubles. In J. Maxwell Atkinson - John Heritage (Eds.) Structures of Social Action. Studies in Conversation Analysis. Cambridge, Cambridge University Press, 346-369.

Kenesei, István, Robert Michael Vago and Fenyvesi Anna. 1998. Hungarian. London: Routledge.

Kiefer, Ferenc. 1983. A kérdő mondatok szemantikájáról és pragmatikájáról [About the semantics and spragmatics of interrogative sentences]. In Rácz Endre-Szathmári István (Eds.) Tanulmányok a mai magyar nyelv szövegtana köréböl, Budapest, Tankönyvkiadó, 203-30.

Kónya, A. 2007. Sémaelméletek és az emlékek fogalmi kategorizációja [Schema theory and conceptual categorization of memories]. In: Csépe V. \& Győri Miklós \& Ragó A. (Eds.): Általános pszichológia 2. Budapest: Osiris Kiadó, 330-347.

Ladd, Robert D. 1981. A First Look at the Semantics and Pragmatics of Negative Questions and Tag Questions. Proceedings of Chicago Linguistic Soceity 17, 164-171.

Laney, Cara and Elisabeth Loftus. 2016. History of Forensic Interviewing. In O'Donohue, W. T.\& Fanetti, M. (Eds.): 
Forensic Interviews Regarding Child Sexual Abuse. New York: Springer, 1-17.

Levinson, Stephen C. 1983. Pragmatics. Cambridge: Cambridge University Press.

Maleczki, Márta. 2007. Szemantika: Szerkezetek jelentése. [Semantics: the meaning of structures] In Alberti G. - Fóris Á. (Eds.) A mai magyar formális nyelvtudomány mühelye. Budapest: Nemzeti Tankönyvkiadó, 124-138.

Nemesi, Attila László. 2011. Nyelv, nyelvhasználat, kommunikáció [Language, language use, communication]. Budapest: Loisir Kiadó.

Ogle, Richard, Allen Parkman and James Porter. 1980. Questions: Leading and Otherwise. Judges Journal, 19: 42-5.

Opeibi, Tunde. 2008. A study of Interrogatives in a selected Nigerian Courtroom discourse. In (Frances Olsen- Alexander Lorz Dieter SteinLanguage and Law: Theory and Society. Dusseldorf University Press.

Oxburgh, Gavin, Trond Myklebust, Tim Grant and Rebecca Milne. 2016. Communication in Investigative and Legal Contexts: Integrated Approaches from Forensic Psychology,Linguistics, and Law Enforcement. Wiley Blackwell.

Reyna, Valerie F., Corbin, Jonathan C., Weldon, Rebecca B. and Brainerd, Charles J. 2016. How fuzzy-trace theory predicts true and false memories for words, sentences, and narratives. Journal od Applied Research in Memory and Cognition 5.1, $1-9$.

Schiffrin, Deborah. 1994. Approaches to Discourse Analysis London: Blackwell

Schirm, Anita 2011: A diskurzusjelölök funkciói: a hát, az $-e$ és a vajon elemek története és jelenkori szinkrón státusa alapján. [The function of Hungarian discourse markers: The history and present synchronic status of the Hungarian elements hát, e and vajon]. Doctoral dissertation, Szeged, Hungary.

Semin, Gün R. and Christianne J. De Poot (1997) The questionanswer paradigm: You might regret not noticing how a question is worded. Journal of Personality and Social Psychology 73/3:472-480.

Sudo, Yasutada (2013) Biased polar questions in English and Japanese. In D. Gutzmann - H-M. Gärtner (szerk.) Beyond 
Marianna Varga: Judicial Complex Strategies...

Expressives. Explorations in Conventional Nontruthconditional Meaning. Leiden: Brill, 277-297.

Tátrai, Szilárd. 2011. Bevezetés a pragmatikába. Funkcionális kognitív megközelités [Introduction to pragmatics. Functional cognitive perspective]. Budapest: Tinta Könyvkiadó.

Varga, Marianna. 2015. Bírói kérdésfeltevések a magyar tanú- és szakértöi bizonyításokban. [Judges' questions in the Hungarian witness testimony and expert evidence] Jelentés és nyelvhasználat 2: 79-107.

Verschueren, Jef. 1999. Understanding Pragmatics. London: Arnold Publishers.

Vrij, Aldert, Christian A. Meissner, Ronald P. Fisher, Saul M. Kassin, Charles A. Morgan and Steven M. Kleinman. 2017. Psychological Perspectives on Interrogation. Perspectives on Psychological Science 1-29.

Walton, Douglas. 2008a. Informal Logic: A Pragmatic Approach. Cambridge: Cambridge University Press.

Walton, Douglas. 2008b. Witness testimony evidence. Argumentation, artificial intelligence, and law. Cambridge: Cambridge University Press. 